\title{
Gene-diet-related factors of hyperglycaemia in postmenopausal women
}

\author{
Bogna Grygiel-Górniak ${ }^{1}$ - Elżbieta Kaczmarek ${ }^{2} \cdot$ Maria Mosor $^{3} \cdot$ Juliusz Przysławski $^{4}$ • Jerzy Nowak ${ }^{3}$
}

Received: 5 August 2017 / Revised: 1 February 2018 / Accepted: 11 February 2018 / Published online: 20 February 2018

(C) The Author(s) 2018. This article is an open access publication

\begin{abstract}
As ageing and increased body fat are the signs of insulin resistance, we have studied whether the presence of Pro12Ala and C1431T of peroxisome proliferator-activated receptor gamma 2 gene and Trp64Arg of beta 3-adrenergic receptor gene may predispose to the hyperglycaemia development in postmenopausal women, who have never undergone hypoglycaemic treatment. The distributions of selected allele and genotype frequencies were determined by the PCR-RFLP method in normo- and hyperglycaemic, who have never been diagnosed and treated for diabetes mellitus were measured. The amount of body fat and lean body mass (LBM) were assessed by the bioimpedance method and nutritional habits by 7-day dietary recall. There were no differences between the distribution of genotypes and the allele frequencies of the Pro12Ala, C1431T and Trp64Arg polymorphisms in normo- and hyperglycaemic women. Hyperglycaemic women were characterized by visceral obesity, hypertension, higher serum insulin and triglycerides, higher intake of fat and lower consumption of complex carbohydrates and B vitamins. Normoglycaemic women with Pro12Pro polymorphism acquired higher energy from dietary fat $(p<0.0276)$ and lower energy from carbohydrates $(p<0.0480)$ than normoglycaemic Ala12 carriers. Subjects with Pro12Pro polymorphism and LBM $>58 \%$ of total body mass or with Trp64Trp and normal triglycerides have higher chance of normoglycaemia. Genotyping for Pro12Ala and Trp64Arg polymorphism in postmenopausal women may have the clinical benefit of predicting hyperglycaemia, thereby contributing to the prevention of diabetes mellitus development in the future. However, not only the genetic background but also the dietary habits (intake of fat, carbohydrates and B vitamins) determine the risk of hyperglycaemia.
\end{abstract}

Keywords Newly diagnosed hyperglycaemia $\cdot$ Postmenopausal obesity $\cdot$ Genetic background $\cdot$ Nutritional habits

Communicated by: Michal Witt

Bogna Grygiel-Górniak

bgrygiel@ump.edu.pl

Elżbieta Kaczmarek

elka@ump.edu.pl

Maria Mosor

m_mosor@man.poznan.pl

Juliusz Przysławski

jprzysla@ump.edu.pl

Jerzy Nowak

nowakjs@man.poznan.pl

1 Department of Rheumatology and Internal Diseases, Poznan University of Medical Sciences, 28 Czerwca Street 135/147, 61545 Poznan, Poland

2 Department of Bioinformatics and Computational Biology, Poznan University of Medical Sciences, Poznan, Poland

3 Institute of Human Genetics, Polish Academy of Sciences, Poznań, Poland

4 Department of Bromatology and Human Nutrition, Poznan University of Medical Sciences, Poznan, Poland

\section{Introduction}

The influence of genetic and nutritional factors is underlined in the development of hyperglycaemia. Many researchers clearly indicate the role of peroxisome proliferator-activated receptor gamma $2(P P A R \gamma 2)$ gene (polymorphisms: Pro12<?thyc $=-$ ? $>$ Alars1801282 and C1431Trs3856806) and beta-3 adrenergic receptor $(A D R \beta 3)$ gene (polymorphism: Trp64Argrs4994) among the candidate genes for hyperglycaemia and development of type 2 diabetes mellitus (Altshuler et al. 2000; Bell and Polonsky 2001; GrygielGórniak 2014). Pro12Pro polymorphism seems to predispose to diabetes mellitus, whereas the presence of Ala allele shows "the protective role" of glycaemic complications (Altshuler et al. 2000). The study of 3914 French Caucasians shows that the 6-year risk of hyperglycaemia was lower in Ala12 carriers than in Pro12Pro subjects (Jaziri et al. 2006). In addition, the Trp64Arg polymorphism of $A D R \beta 3$ gene is associated with insulin resistance in both diabetic (Burguete-Garcia et al. 2014) and non-diabetic obese patients (de Luis et al. 2007). 
The Arg64 variant is related to overweight, obesity and early onset of type 2 diabetes mellitus (Oeveren van-Dybicz et al. 2001), whereas the Trp64Trp polymorphism is associated with the highest effect of body mass reduction during lowenergy diet and physical activity (de Luis et al. 2007).

Not only the genetic predisposition but also the unbalanced diet (intake of high fat and low amount of complex carbohydrate) can have an impact on glucose disorders (Post et al. 2012; Schulze et al. 2004; WHO 2003; Yoo et al. 2004; GrygielGorniak et al. 2016). Recent studies have indicated that many vitamins of group B have beneficial influence on the glucose regulation (Agulló-Ortuño et al. 2002; Al-Maskari et al. 2012; Chow and Stone 1957; Gargari et al. 2011; Huang et al. 2013; Lazalde-Ramos et al. 2012; Sahin et al. 2013; Sasaki et al. 2012; Sudchada et al. 2012). Adequate vitamin $\mathrm{B}_{12}$ intake decreases the risk of hyperglycaemia (Chow and Stone 1957), whereas folate supplementation improves glycaemic control in diabetic patients (Gargari et al. 2011). Biotin beneficially influences the expression of the glucose transporter protein 4 (GLUT4) (Sahin et al. 2013; Sasaki et al. 2012). Pantothenic acid is synthesized during the activity of the vinin- 1 , which under fasting conditions modulates the glucose metabolism (Bell and Polonsky 2001). These data elucidate the important role of B vitamins in hyperglycaemia and underline their positive anti-diabetic effect (Lazalde-Ramos et al. 2012; Jianbo et al. 2011).

In view of the contentious association of PPAR $\gamma 2$ and $A D R \beta 3$ genes with hyperglycaemia, this study was planned to analyse selected polymorphisms of nutritional status, dietary habits and metabolic disorders in two groups of women who were diagnosed of impaired fasting glucose for the first time and never treated with hypoglycaemic medications.

\section{Material and methods}

\section{Analysed group}

The study included 271 postmenopausal women who have never been diagnosed and treated for hyperglycaemia or diabetes mellitus. They have been selected from 1431 subjects who were under the control of outpatient metabolic clinic. The postmenopausal period was assessed including the time ( 2 years from the last menorrhea) and hormonal criterion (serum follicle-stimulating hormone [FSH] concentration). Moreover, women with essential diseases such as nontreated thyroidal disorders, acute liver and renal diseases, neoplasm diagnosed during the past 5 years, acute infections and smoking, alcohol abuse or consumption of vitamins or mineral supplements were excluded from the study. All measurements (anthropometric and nutritional) were done using professional instruments, and a written informed consent was obtained from every woman enrolled in this study. This study was approved by the local Bioethics Committee of Poznan
University of Medical Sciences (no. 792/09) and was performed according to the Helsinki Declaration.

\section{Blood pressure measurement}

Blood pressure was measured by the auscultatory method with a mercury sphygmomanometer in the nondominant arm of the patient, after a 10-min rest in the upright seated position (between 7:00 am and 11:00 am after an overnight fast). Hypertension was defined as a systolic blood pressure (SBP) $\geq 140 \mathrm{mmHg}$ and/or a diastolic blood pressure (DBP) $\geq$ $90 \mathrm{mmHg}$ according to the recent guidelines of the European Society of Hypertension's Working Group on Blood Pressure Monitoring (O’Brien et al. 2003).

\section{Anthropometric measurements}

All the subjects were informed about the fasting and the anthropometric and biochemical analyses. Anthropometric measurements were done according to the current recommendations (Ness-Abramof and Apovian 2008), and the following components were included: body weight $(\mathrm{kg}$; by a calibrated electronic scale to the nearest $0.1 \mathrm{~kg}$, bare feet, in light clothing), body height $(\mathrm{cm}$; by a vertical ruler to the nearest $0.5 \mathrm{~cm})$, waist circumference $(\mathrm{cm}$; to the nearest $0.1 \mathrm{~cm}$, midway between the lower border of the ribs and the iliac crest at the widest portion) and hip circumference $(\mathrm{cm}$; to the nearest $0.1 \mathrm{~cm}$, at the widest diameter of the buttocks). Waist-to-hip ratio (WHR) and body mass index (BMI; body weight/ body height squared; $\mathrm{kg} / \mathrm{m}^{2}$ ) were calculated according to World Health Organization (WHO) recommendations (WHO 2000). A high WHR $>0.85$ in women indicated the visceral (abdominal) fat accumulation (WHO 2000). All anthropometric components were measured twice by study staff using a standardized protocol and averaged. The body fat mass and lean body mass (LBM) were assessed by the bioimpedance method using BODYSTAT 1500 - a singlefrequency device (50 kHz; Bodystat Ltd., Isle of Man, UK).

\section{Nutritional analysis}

Nutritional intake was determined using an in-house developed 7-day estimated dietary record during normal diet (Charzewska 1998). The patients were trained to fill the questionnaires and qualified personnel verified the completed forms. The results of questionnaire studies were analysed based on the tables for the composition and nutrition value of food products (Kunachowicz et al. 1998). The intake of the analysed nutrients was compared with the recommended norms published by the National Institute of Food and Nutrition in Warsaw, Poland (Jarosz and BulhakJachymczyk 2013). According to the data, the reduction of the intake of B vitamins was 20\% (Jarosz and BulhakJachymczyk 2013). The dietary intake of B vitamins was 
compared to the recommended norms of WHO statement and Polish recommendations, and the estimated average requirements (EAR) were as follows: $2 \mu \mathrm{g}$ /day of vitamin $\mathrm{B}_{12}$ (EAR), $320 \mu \mathrm{g} /$ day of folate (EAR), $5 \mathrm{mg}$ /day adequate intake (AI) of pantothenic acid and $30 \mu \mathrm{g} /$ day of biotin (AI) (Jarosz and Bulhak-Jachymczyk 2013; Food and Nutrition Board, Institute of Medicine, Natl Acad Board, Institute of Medicine 2000; WHO 2004). The dietary fibre intake was compared with the nutritional prophylaxis recommendation, which ranges from 27 to $40 \mathrm{~g}$ /day (Jarosz and BulhakJachymczyk 2013).

\section{Biochemical analysis}

Blood samples were taken between 7:00 am and 8:00 am after an overnight fast. Venous blood samples were collected in ethylenediaminetetraacetic acid-containing tubes, which were immediately centrifuged. Plasma glucose and lipid profiles (total cholesterol [TC], high-density lipoprotein [HDL] and triglycerides [TG]) were measured using enzymatic colorimetric assays (Cobas Integra 400 Plus; Roche Diagnostics, Indianapolis, IN). Low-density lipoprotein (LDL) was calculated from serum TC, TG and HDL according to the Friedewald equation (Friedewald et al. 1972). FSH serum levels were measured via specific chemiluminescence assays (Roche Diagnostics). Plasma insulin levels were determined by using an enzymatic immunoassay (Cobas Integra 400 Plus). Insulin resistance was estimated by homeostasis model assessment (HOMA) according to the formula: HOMA-insulin resistance $($ HOMA $-\mathrm{IR})=$ fasting plasma glucose $(\mathrm{mmol} / \mathrm{L}) \times$ fasting insulin $(\mathrm{mU} / \mathrm{L}) \quad 22.5$.

According to the European Society of Cardiology, analysed women were classified into two groups: normoglycaemic and hyperglycaemic based on venous fasting plasma glucose (FPG) (Rydén et al. 2013). An FPG $\leq 99 \mathrm{mg} / \mathrm{dL}$ (< $5.6 \mathrm{mmol} / \mathrm{L}$ ) was normal, whereas $\mathrm{FPG} \geq 100 \leq 125 \mathrm{mg} / \mathrm{dL}$ ( $\geq 5.6 \leq 6.9 \mathrm{mmol} / \mathrm{L}$ ) was classified as impaired fasting glucose (Buysschaert and Bergman 2011; Rydén et al. 2013).

\section{Statistical analysis}

The distribution of selected genotype and allele frequencies was analysed using Pearson's chi-square test or Fisher's exact test (for small frequencies) with calculated odds ratios (ORs).

Table 1 Genotype and allele frequencies of the Pro12Ala and C1431/X PPAR gamma 2 and Trp64Arg of beta-adrenergic receptor gene polymorphisms according to normoglycaemic (glucose $<100 \mathrm{mg} / \mathrm{dl}$ ) and hyperglycaemic state (glucose $>100 \mathrm{mg} / \mathrm{dl}$ ). Data are $n(\%)$ for genotypes and $n$ (frequency) for alleles

\begin{tabular}{|c|c|c|c|c|c|c|c|}
\hline \multirow[t]{2}{*}{ Body fat distribution } & \multicolumn{2}{|l|}{$\begin{array}{l}\text { Normoglycaemic } \\
<100 \mathrm{mg} / \mathrm{dl} \\
N=194\end{array}$} & \multicolumn{2}{|l|}{$\begin{array}{l}\text { Hyperglycaemic } \\
\geq 100 \mathrm{mg} / \mathrm{dl} \\
N=77\end{array}$} & \multirow[t]{2}{*}{ OR } & \multirow[t]{2}{*}{$95 \% \mathrm{CI}$} & \multirow[t]{2}{*}{$p$ value } \\
\hline & Observed $n(\%)$ & Expected $(\%)$ & Observed $n(\%)$ & Expected (\%) & & & \\
\hline \multicolumn{8}{|l|}{ Genotype (Pro12Ala) } \\
\hline CC (Pro12Pro) & $130(67)$ & $133(68.6)$ & $55(71.4)$ & $53(68.8)$ & 0.81 & $0.46-1.45$ & ns \\
\hline CG (Pro12Ala) & $57(29.4)$ & $54(27.8)$ & $19(24.7)$ & $22(27.3)$ & 1.23 & $0.69-2.19$ & $\mathrm{~ns}$ \\
\hline GG (Ala12Ala) & $7(3.6)$ & $7(3.6)$ & $3(3.9)$ & $3(3.9)$ & - & - & \\
\hline \multicolumn{8}{|l|}{ Allele } \\
\hline $\mathrm{C}$ & $317(81.70)$ & - & $129(83.77)$ & - & & & \\
\hline G & $71(18.30)$ & - & $25(16.23)$ & - & & & \\
\hline \multicolumn{8}{|l|}{ Genotype (C1431T) } \\
\hline $\mathrm{CC}(\mathrm{C} 1431 \mathrm{C})$ & $143(73.7)$ & $157(80.9)$ & $55(71.4)$ & $63(81.8)$ & 1.21 & $0.62-2.02$ & ns \\
\hline $\mathrm{CT}(\mathrm{C} 1431 \mathrm{~T})$ & $47(24.2)$ & $34(17.5)$ & $19(24.7)$ & $13(16.9)$ & 0.89 & $0.49-1.61$ & ns \\
\hline TT (T1431 T) & $4(2.1)$ & $3(1.5)$ & $3(3.39)$ & $1(1.3)$ & - & & \\
\hline \multicolumn{8}{|l|}{ Allele } \\
\hline $\mathrm{C}$ & $333(85.82)$ & - & $129(83.77)$ & - & & & \\
\hline $\mathrm{T}$ & $55(14.18)$ & - & $25(16.23)$ & - & & & \\
\hline \multicolumn{8}{|l|}{ Genotype (Trp64Arg) } \\
\hline TT (Trp64Trp) & $159(81.9)$ & $142(73.2)$ & 61 & $56(72.7)$ & 1.19 & $0.62-2.31$ & $\mathrm{~ns}$ \\
\hline TC (Trp64Arg) & $31(16)$ & $47(24.2)$ & 16 & $19(24.7)$ & 0.84 & $0.43-1.63$ & ns \\
\hline CC (Arg64Arg) & $4(2.1)$ & $5(2.6)$ & - & $2(2.6)$ & & & \\
\hline \multicolumn{8}{|l|}{ Allele } \\
\hline $\mathrm{T}$ & 349 (89.95) & - & 138 (89.61) & - & & & \\
\hline $\mathrm{C}$ & $39(10.05)$ & - & $16(10.39)$ & - & & & \\
\hline
\end{tabular}


The expected frequencies of genotypes were determined by Hardy-Weinberg equilibrium deviation. The results of the study (continuous variables) were first verified according to the consistence with the normal distribution using the Shapiro-Wilk test. Generally, if the data passed the normality test, it was followed by parametric tests to compare the means (i.e. Student's $t$ test for two independent groups or one-way analysis of variance for more than two independent groups); otherwise, the nonparametric Mann-Whitney $U$ test was used. The following variables were significantly different according to glucose level: BF, LBM, SBP, DBP, insulin, HDL, TG, intake of energy from fat and carbohydrates, vitamin $\mathrm{B}_{12}$, biotin and the Mann-Whitney $U$ test. Then, the multivariate analysis by means of using classification trees was performed to find the continuous variables that are significantly associated with the studied polymorphisms and glucose. Quick, unbiased and efficient statistical tree (QUEST) algorithm was used for the analysis of classification trees. Two variables were found to be significantly associated with glucose in relation to polymorphisms: LBM and TG. In addition, ORs with 95\% confidence interval were determined for hyperglycaemia related with the results of TG and LBM exceeding the norms. The statistical analysis was performed by using Statistica v. 12.0 (StatSoft, Inc.)

\section{Results}

We did not find the differences (calculated by chi-square test) between the distribution of genotype and allele frequencies of the Pro12Ala, C1431T and Trp64Arg polymorphisms in two analysed groups of women, normo- and hyperglycaemic, and no significant deviation from the Hardy-Weinberg equilibrium was observed in our population (Table 1). Hyperglycaemic
Table 2 Anthropometric, biochemical and nutritional characteristics of normo- and hyperglycaemic women

\begin{tabular}{|c|c|c|c|}
\hline Analysed parameters & $\begin{array}{l}\text { Normoglycaemic } \\
<100 \mathrm{mg} / \mathrm{dl} \\
N=194\end{array}$ & $\begin{array}{l}\text { Hyperglycaemic } \\
\geq 100 \mathrm{mg} / \mathrm{dl} \\
N=77\end{array}$ & $p$ value \\
\hline Age (years) & $58.73 \pm 5.58$ & $60.77 \pm 4.89$ & 0.0055 \\
\hline Body height $(\mathrm{cm})$ & $161.13 \pm 6.02$ & $160.47 \pm 5.25$ & 0.4048 \\
\hline Body mass (kg) & $74.12 \pm 16.52$ & $82.02 \pm 14.44$ & 0.0003 \\
\hline $\mathrm{WC}(\mathrm{cm})$ & $87.91 \pm 14.66$ & $96.61 \pm 11.20$ & 0.00001 \\
\hline WHR & $0.83 \pm 0.08$ & $0.86 \pm 0.06$ & 0.0002 \\
\hline BMI $\left(\mathrm{kg} / \mathrm{m}^{2}\right)$ & $28.49 \pm 6.35$ & $31.76 \pm 5.63$ & 0.0001 \\
\hline Body fat $(\%)$ & $42.40 \pm 6.63$ & $46.16 \pm 6.22$ & 0.00001 \\
\hline $\operatorname{LBM}(\%)$ & $57.74 \pm 6.51$ & $53.77 \pm 6.32$ & 0.00001 \\
\hline Systolic pressure (mmHg) & $137.06 \pm 21.45$ & $151.73 \pm 21.86$ & 0.00001 \\
\hline Diastolic pressure $(\mathrm{mmHg})$ & $86.08 \pm 12.73$ & $92.77 \pm 14.50$ & 0.0002 \\
\hline FSH (mIU/ml) & $74.10 \pm 20.77$ & $59.89 \pm$ & 0.0001 \\
\hline Insulin (U/ml) & $8.57 \pm 7.32$ & $12.49 \pm 7.26$ & 0.0001 \\
\hline Glucose (mg/dl) & $90.28 \pm 6.53$ & $112.37 \pm 13.77$ & 0.00001 \\
\hline HOMA-IR $[(\mathrm{mU} / \mathrm{ml}) \times(\mathrm{mmol} / \mathrm{l}))]$ & $1.93 \pm 1.64$ & $3.53 \pm 2.33$ & 0.00001 \\
\hline $\mathrm{TC}(\mathrm{mg} / \mathrm{dl})$ & $228.01 \pm 39.96$ & $238.10 \pm 42.77$ & 0.0673 \\
\hline HDL (mg/dl) & $65.38 \pm 14.94$ & $60.50 \pm 13.55$ & 0.0135 \\
\hline $\mathrm{TG}(\mathrm{mg} / \mathrm{dl})$ & $105.56 \pm 41.93$ & $147.56 \pm 67.58$ & 0.0000 \\
\hline LDL (mg/dl) & $141.55 \pm 35.99$ & $148.02 \pm 38.36$ & 0.1914 \\
\hline Energy (kcal) & $2046.39 \pm 552.40$ & $2057.39 \pm 575.11$ & 0.8839 \\
\hline Protein (\% energy) & $16.27 \pm 3.37$ & $16.39 \pm 3.09$ & 0.8002 \\
\hline Fat (\% energy) & $33.58 \pm 5.46$ & $35.19 \pm 4.70$ & 0.0238 \\
\hline Carbohydrates (\% energy) & $51.03 \pm 6.92$ & $49.19 \pm 6.05$ & 0.0421 \\
\hline Dietary fibre $(\mathrm{g})$ & $22.75 \pm 7.46$ & $21.50 \pm 7.01$ & 0.2056 \\
\hline Vitamin B12 $(\mu \mathrm{g})$ & $2.97 \pm 2.52$ & $2.31 \pm 1.65$ & 0.0352 \\
\hline Biotyna $(\mu \mathrm{g})$ & $25.37 \pm 11.54$ & $22.36 \pm 10.53$ & 0.0479 \\
\hline Pantothenic acid (mg) & $3.19 \pm 1.17$ & $2.81 \pm 1.10$ & 0.0164 \\
\hline Free folacin $(\mu \mathrm{g})$ & $115.82 \pm 43.69$ & $104.27 \pm 39.39$ & 0.0447 \\
\hline Total folacin $(\mu \mathrm{g})$ & $234.13 \pm 86.69$ & $211.79 \pm 73.46$ & 0.0472 \\
\hline
\end{tabular}




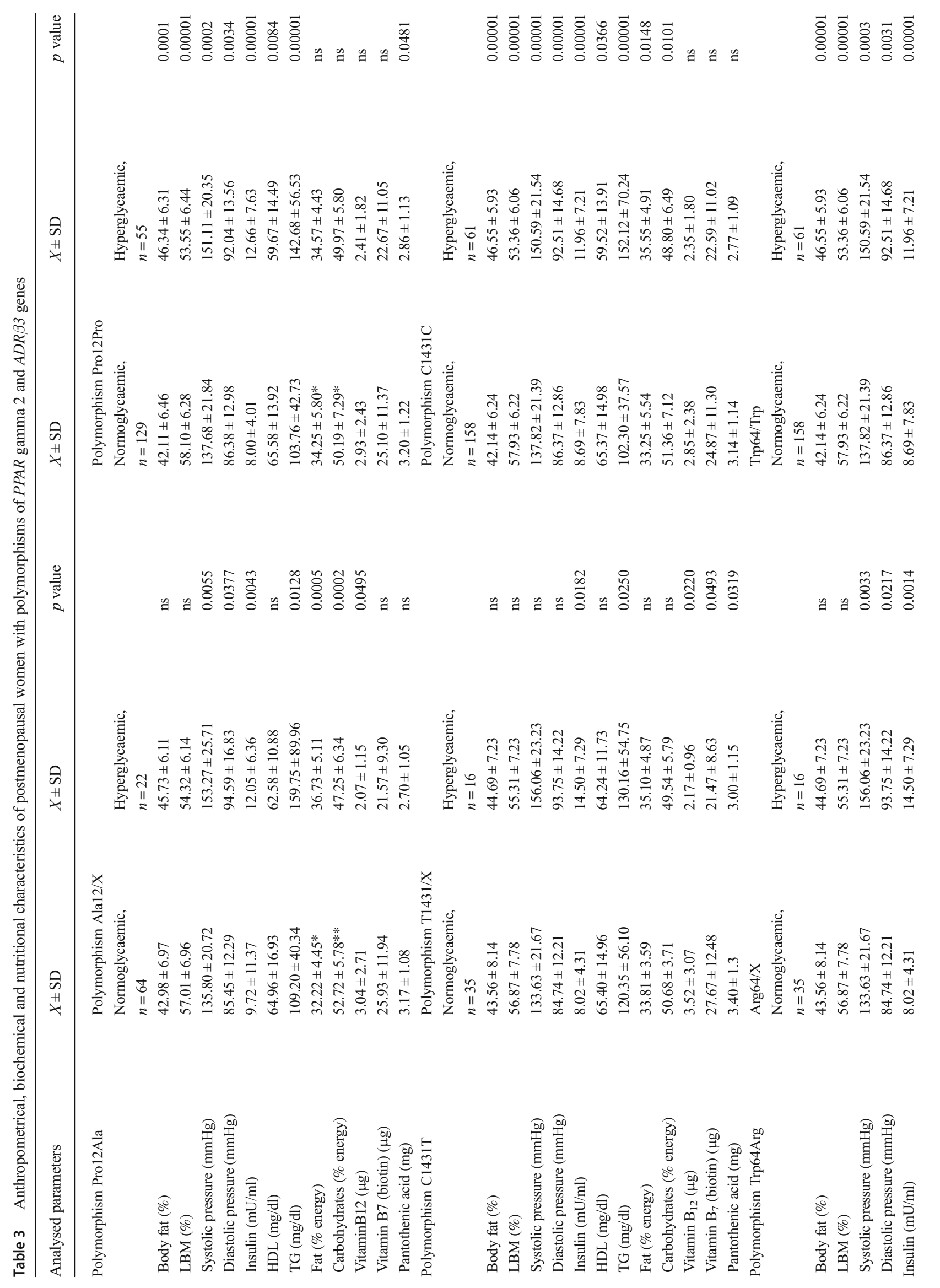


women (Table 2) have been found to be older than normoglycaemic women and were characterized with higher body mass, waist circumference, WHR, BMI, body fat amount, blood pressure (both diastolic and systolic), serum insulin, TG, calculated HOMA-IR, lower FSH level and higher intake of energy from fat. Moreover, they consume lower energy from the carbohydrates and lower amount of vitamins from group $B$ (vitamin $\mathrm{B}_{12}$, biotin, pantothenic acid and folacin).

The detailed data presented in Table 3 show the differences of analysed parameters between selected polymorphisms in normo- and hyperglycaemic women. Independent of the analysed polymorphism, hyperglycaemic women were characterized by lower LBM and serum HDL, lower intake of carbohydrates and B vitamins, higher body fat amount, SDP and DBP, serum insulin and TG, as well as dietary fat intake (in most cases, the differences were statistically significant). However, the analysis of Pro12Pro polymorphism has shown that the normoglycaemic women consumed higher energy from dietary fat $(p<0.0276)$ and lower energy from carbohydrates $(p<0.0480)$ compared to normoglycaemic women with Ala12/X polymorphism.

Independent of the glycaemic state, women characterized by Pro12Pro polymorphism and higher amount of LBM (> $58 \%$ of body mass) had higher chance of normal glucose level compared to women with lower LBM $(p=0.0007 ; 74.2 \%$ of analysed subjects were normoglycaemic) (Table 4). In addition, women with Trp64Trp polymorphism and low level of TG had higher chance of normoglycaemic condition than women with hypertriglyceridaemia ( $\mathrm{TG} \geq 150 \mathrm{mg} / \mathrm{dL}, p=$ 0.0002).

\section{Discussion}

The hyperglycaemic state was first time diagnosed in $28.4 \%$ of analysed women ( $n=77$; average venous FPG was 112.37 $\pm 13.77 \mathrm{mg} / \mathrm{dL}$ ). Analysed women were never treated with diabetic diet or anti-diabetic medications. Hyperglycaemic women were older than normoglycaemic women, which may reflect the fact that the risk of hyperglycaemia and diabetes mellitus increased with age (Halter et al. 2014). Moreover, they were viscerally obese (BMI $>30 \mathrm{~kg} / \mathrm{m}^{2}$, WHR $\geq 0.85$ ) (WHO 2000). Ageing and, in particular, menopause transition are associated with increased prevalence of abdominal fat deposition and metabolic disorders (Carr and Brunzell 2004). In this study, hyperglycaemic women had worse metabolic profile (higher serum TG, TC and calculated HOMA-IR), which increased the risk of the diabetes mellitus and cardiovascular disease (CVD) development in the future (Carr and Brunzell 2004). Their blood pressures were elevated, and the DBP was also increased in normoglycaemic overweight women. 
Table 4 Analysis of the risk of hyperglycaemia in analysed groups

\begin{tabular}{llllll}
\hline Analysed polymorphism & Analysed groups & $n$ & $\%$ & $n$ & $\%$ \\
\hline Pro12Pro & & LBM $>58 \%$ & & LBM $\leq 58$ & \\
& Normoglycaemic & 184 & 74.2 & 17 & 51.5 \\
& Hyperglycaemic & 64 & 25.8 & 16 & 48.5 \\
& Sum & 248 & 100 & 33 & 100 \\
& & OR $=3.44$ & $(1.69-7.01)$ & OR $=0.29$ & $(0.14-0.59)$ \\
Trp64Trp & $p=0.0007$ & & & \\
& & TG $\leq 150 \mathrm{mg} / \mathrm{dl}$ & $\mathrm{TG}>150 \mathrm{mg} / \mathrm{dl}$ \\
& Normoglycaemic & 140 & 80.5 & 19 & 41.3 \\
& Hyperglycaemic & 40 & 19.5 & 21 & 58.7 \\
& Sum & 180 & 100 & 46 & 100 \\
& & OR=3.87 & $(1.90-7.89)$ & OR $=0.26$ & $(0.13-0.53)$ \\
\hline
\end{tabular}

Even the energy intake was found to be within the recommended level, and the daily food ratios were improperly balanced and contained excess of fat along with insufficient consumption of carbohydrates. The high percentage of energy from fat is epidemiologically alerting, and the amount of this nutrient should not exceed $30 \%$ of daily energy intake in general population; however, if the BMI is $>25 \mathrm{~kg} / \mathrm{m}^{2}$ (like in this study), the value should not be higher than $25 \%$ of energy from this component (Jarosz and Bulhak-Jachymczyk 2013; WHO 2003). The low percentage of energy from carbohydrates did not achieve the recommended amount of 55-75\% of energy intake (including minimum 50-70\% polysaccharides) (WHO 2003). In addition, low intake of dietary fibre is the risk of hyperglycaemic complications (WHO 2003). It was proved that the diet composed of high complex carbohydrates and dietary fibre is beneficial in the reduction of body mass and diabetes mellitus development (Post et al. 2012).

Besides the basic dietary components, adequate consumption of B vitamins also has beneficial influence on the glycaemic state. Unfortunately, in this study, only the intake of vitamin $\mathrm{B}_{12}$ was proper, whereas the intake of other vitamins from group B (folate, biotin and pantothenic acid) was lower than the recommended level (Jarosz and BulhakJachymczyk 2013; Food and Nutrition Board, Institute of Medicine, Natl Acad Board, Institute of Medicine 2000; WHO 2004). Considering the role of B vitamins in carbohydrate metabolism, their low intake in the analysed group may increase the risk of hyperglycaemia. Cobalamin not only has anti-oxidative properties (Al-Maskari et al. 2012; Huang et al. 2013) but also participates in the utilisation of carbohydrates (Chow and Stone 1957), whereas folate modulates the glucose metabolism (Lazalde-Ramos et al. 2012). Folate supplementation decreases glycosylated haemoglobin, fasting blood glucose, insulin and homocysteine in type 2 diabetes mellitus patients (Gargari et al. 2011). The AI of biotin (which increases GLUT4 and raises insulin sensitivity in skeletal muscle) (Sahin et al. 2013; Sasaki et al. 2012) and proper pantothenic acid consumption (Chen et al. 2014) cause an anti-diabetic effect.

In Table 3, we have presented the detailed analysis of body components, metabolic parameters and nutritional factors in the discussed groups of women. Most differences between normo- and hyperglycaemic women were observed within the same polymorphism. However, normoglycaemic women with Ala allele consumed lower energy from fat and higher energy from carbohydrates than normoglycaemic women with Pro12Pro polymorphism. Many studies showed that Ala12 polymorphism is related to insulin sensitivity (Douglas et al. 2001; Ek et al. 2001), and a meta-analysis of Altshuler et al. has revealed a significant reduction of risk of diabetes of $21 \%$ in subjects with Ala allele (Lazalde-Ramos et al. 2012).

Women with Pro12Pro polymorphism (normo- and hyperglycaemic) and higher LBM (> 58\% of body mass) have bigger chance of normal glucose level compared to subjects with lower LBM (Table 4). Thus, besides the predisposition of Pro12Pro to hyperglycaemia and diabetes mellitus development (Bell and Polonsky 2001; Jaziri et al. 2006), the high LBM (which could be caused by increased physical activity) can prevent the glycaemic complication. Many studies have confirmed that the subjects with high muscle mass and regular physical activity had lower risk of diabetes mellitus (Lee et al. 2010; Shishikura et al. 2014). In addition, women with Trp64Trp polymorphism and low level of TG have higher chance of normoglycaemic state than women with hypertriglyceridaemia. In the reference data, the Trp64Arg allele is associated with lower risk of insulin resistance in diabetic (Burguete-Garcia et al. 2014) and non-diabetic obese patients (de Luis et al. 2007), whereas the Arg64 variant is reported to be related to overweight, obesity and early onset of type 2 diabetes mellitus (Oeveren van-Dybicz et al. 2001; Zhan and Ho 2005). Moreover, high TG level is one of the components of metabolic syndrome and coexists with hyperglycaemia (Alberti et al. 2009; Weitgasser et al. 2004). In this study, women with Trp64Trp polymorphism and 
normal TG level were mainly predicted by normal glucose level, which indicates the beneficial influence of this polymorphism on metabolic parameters.

\section{Conclusion}

The risk factors of hyperglycaemia in postmenopausal women include high body mass and body fat, visceral distribution of fat, low LBM and improperly balanced diet (high fat intake and lower amount of complex carbohydrates and B vitamins). The presence of Pro12Pro genotype is related to higher risk of diabetes mellitus and is associated with worse dietary habits; however, this risk is reduced in subjects with higher muscle mass. Moreover, the normal TG level in women withTrp64Trp polymorphism predicts normoglycaemia. Thus, the predisposition to hyperglycaemia is multifactorial; not only the genetic background but also dietary habits (fat overnutrition and intake of low B vitamins) influence the risk of high glucose level and might precede diabetes mellitus development.

Acknowledgements This study was supported by the Polish National Science Centre under grant No. N404 504638.

\section{Compliance with ethical standards}

Conflict of interest The authors declare that they have no conflict of interest.

Open Access This article is distributed under the terms of the Creative Commons Attribution 4.0 International License (http:// creativecommons.org/licenses/by/4.0/), which permits unrestricted use, distribution, and reproduction in any medium, provided you give appropriate credit to the original author(s) and the source, provide a link to the Creative Commons license, and indicate if changes were made.

\section{References}

Agulló-Ortuño MT, Albaladejo MD, Parra S, Rodríguez-Manotas M, Fenollar M, Ruíz-Espejo F et al (2002) Plasmatic homocysteine concentration and its relationship with complications associated to diabetes mellitus. Clin Chim Acta 326:105-112

Alberti KG, Eckel RH, Grundy SM, Zimmet PZ, Cleeman JI, Donato KA et al (2009) International Diabetes Federation Task Force on Epidemiology and Prevention; National Heart, Lung, and Blood Institute; American Heart Association; World Heart Federation; International Atherosclerosis Society; International Association for the Study of Obesity. Harmonizing the metabolic syndrome: a joint interim statement of the International Diabetes Federation Task Force on Epidemiology and Prevention; National Heart, Lung, and Blood Institute; American Heart Association; World Heart Federation; International Atherosclerosis Society; and International Association for the Study of Obesity. Circulation 120:1640-1645

Al-Maskari MY, Waly MI, Ali A, Al-Shuaibi YS, Ouhtit A (2012) Folate and vitamin B12 deficiency and hyperhomocysteinemia promote oxidative stress in adult type 2 diabetes. Nutrition 28:e23-e26
Altshuler D, Hirschhorn JN, Klannemark M, Lindgren CM, Vohl MC, Nemesh J et al (2000) The common PPARg Pro12Ala polymorphism is associated with decreased risk of type 2 diabetes. Nat Genet 26:76-80

Bell GI, Polonsky KS (2001) Diabetes mellitus and genetically programmed defects in beta-cell function. Nature 414:788-791

Burguete-Garcia AI, Martinez-Nava GA, Valladares-Salgado A, Bermudez Morales VH, Estrada-Velasco B, Wacher N et al (2014) Association of $\beta 1$ and $\beta 3$ adrenergic receptors gene polymorphisms with insulin resistance and high lipid profiles related to type 2 diabetes and metabolic syndrome. Nutr Hosp 29:1327-1334

Buysschaert M, Bergman M (2011) Definition of prediabetes. Med Clin N Am 95:289-297

Carr MC, Brunzell JD (2004) Abdominal obesity and dyslipidemia in the metabolic syndrome: importance of type 2 diabetes and familial combined hyperlipidemia in coronary artery disease risk. J Clin Endocrinol Metab 89:2601-2607

Charzewska J (1998) Instruction of the dietary recall gathering from the last 24 hours. Press National Food and Nutrition Institute, Warsaw (in Polish)

Chen S, Zhang W, Tang C, Tang X, Liu L, Liu C (2014) Vanin-1 is a key activator for hepatic gluconeogenesis. Diabetes 63:2073-2085

Chow BF, Stone HH (1957) The relationship of vitamin B12 to carbohydrate metabolism and diabetes mellitus. Am J Clin Nutr 5:431-439

de Luis DA, Gonzalez Sagrado M, Aller R, Izaola O, Conde R (2007) Influence of the Trp64Arg polymorphism in the beta 3 adrenoreceptor gene on insulin resistance, adipocytokine response, and body weight loss secondary to lifestyle modification in obese patients. Eur J Intern Med 18:587-592

Douglas JA, Erdos MR, Watanabe RM, Braun A, Johnston CL, Oeth P et al (2001) The peroxisome proliferator-activated receptor- $\gamma 2$ Pro12Ala variant association with type 2 diabetes and trait differences. Diabetes 50:886-890

Ek J, Andersen G, Urhammer SA, Hansen L, Carstensen B, BorchJohnsen K et al (2001) Studies of the Pro12Ala polymorphism of the peroxisome proliferator-activated receptor-gamma2 (PPARgamma2) gene in relation to insulin sensitivity among glucose tolerant Caucasians. Diabetologia 44:1170-1176

Food and Nutrition Board, Institute of Medicine, Natl Acad Board, Institute of Medicine (2000) Dietary reference intakes for thiamin, riboflavin, niacin, vitamin B6, folate, vitamin B12, pantothenic acid, biotin, and choline. National Academic Press, Washington DC

Friedewald WT, Levy RI, Fredrickson DS (1972) Estimation of the concentration of low-density lipoprotein cholesterol in plasma, without use of the preparative ultracentrifuge. Clin Chem 18:499-502

Gargari BP, Aghamohammadi V, Aliasgharzadeh A (2011) Effect of folic acid supplementation on biochemical indices in overweight and obese men with type 2 diabetes. Diabetes Res Clin Pract 94:33-38

Grygiel-Górniak B (2014) Peroxisome proliferator-activated receptors and their ligands: nutritional and clinical implications - a review. Nutr J 13:17

Grygiel-Gorniak B, Mosor M, Marcinkowska J, Przyslawski J, Nowak J (2016) Impact of the PPAR gamma-2 gene polymorphisms on the metabolic state of postmenopausal women. J Biosci 41(3):427-437

Halter JB, Musi N, McFarland Horne F et al (2014) High: diabetes and cardiovascular disease in older adults: current status and future directions. Diabetes 63:2578-2589

Huang T, Ren J, Huang J, Li D (2013) Association of homocysteine with type 2 diabetes: a meta-analysis implementing Mendelian randomization approach. BMC Genomics 14:867

Jarosz M, Bulhak-Jachymczyk B (2013) Recommended values of human nutrition. The background of obesity and non-communicable diseases prevention. Medical Publishing Company PZWL, Warsaw (in Polish)

Jaziri R, Lobbens S, Aubert R, Péan F, Lahmidi S, Vaxillaire M, DESIR Study Group et al (2006) The PPARG Pro12Ala polymorphism is 
associated with a decreased risk of developing hyperglycemia over 6 years and combines with the effect of the APM1 G-11391A single nucleotide polymorphism: the data from an epidemiological study on the insulin resistance syndrome (DESIR) study. Diabetes 55: $1157-1162$

Jianbo L, Yuche C, Ming S, Jingrong T, Qing D, Yu Z et al (2011) Association of homocysteine with peripheral neuropathy in Chinese patients with type 2 diabetes. Diabetes Res Clin Pract 93: $38-42$

Kunachowicz H, Nadolna I, Przygoda B, Iwanow K (1998) Tables of nutritious value of food products. Press National Food and Nutrition Institute, Warsaw (in Polish)

Lazalde-Ramos BP, Zamora-Perez AL, Sosa-Macías M, GuerreroVelázquez C, Zúñiga-González GM (2012) DNA and oxidative damages decrease after ingestion of folic acid in patients with type 2 diabetes. Arch Med Res 43:476-481

Lee JS, Auyeung TW, Leung J, Kwok T, Leung PC, Woo J (2010) The effect of diabetes mellitus on age-associated lean mass loss in 3153 older adults. Diabet Med 27:1366-1371

Ness-Abramof R, Apovian CM (2008) Waist circumference measurement in clinical practice. Nutr Clin Pract 23:397-404

O’Brien E, Asmar R, Beilin L, Imai Y, Mallion JM, Mancia G, European Society of Hypertension Working Group on Blood Pressure Monitoring et al (2003) European Society of Hypertension recommendations for conventional ambulatory and home blood pressure measurement. J Hypertens 21:821-848

Oeveren van-Dybicz AM, Vonkeman HE, Bon MA, van den Bergh FA, Vermes I (2001) 3-Adrenergic receptor gene polymorphism and type 2 diabetes in a Caucasian population. Diabetes Obes Metab 3:47-51

Post RE, Mainous AG 3rd, King DE, Simpson KN (2012) Dietary fiber for the treatment of type 2 diabetes mellitus: a meta-analysis. J Am Board Fam Med 25:16-23

Rydén L, Grant PJ, Anker SD, Berne C, Cosentino F, Danchin N et al (2013) ESC guidelines on diabetes, pre-diabetes, and cardiovascular diseases developed in collaboration with the EASD: the task force on diabetes, pre-diabetes, and cardiovascular diseases of the European Society of Cardiology (ESC) and developed in collaboration with the European Association for the Study of Diabetes (EASD). Eur Heart J 34:3035-3087
Sahin K, Tuzcu M, Orhan C, Sahin N, Kucuk O, Ozercan IH et al (2013) Anti-diabetic activity of chromium picolinate and biotin in rats with type 2 diabetes induced by high-fat diet and streptozotocin. Br J Nutr 110:197-205

Sasaki Y, Sone H, Kamiyama S, Shimizu M, Shirakawa H, Kagawa Y et al (2012) Administration of biotin prevents the development of insulin resistance in the skeletal muscles of Otsuka Long-Evans Tokushima Fatty rats. Food Funct 3:414-419

Schulze MB, Manson JE, Ludwig DS, Colditz GA, Stampfer MJ, Willett WC et al (2004) Sugar-sweetened beverages, weight gain, and incidence of type 2 diabetes in young and middle-aged women. JAMA 292:927-934

Shishikura K, Tanimoto K, Sakai S, Tanimoto Y, Terasaki J, Hanafusa T (2014) Association between skeletal muscle mass and insulin secretion in patients with type 2 diabetes mellitus. Endocr J 61:281-287

Sudchada P, Saokaew S, Sridetch S, Incampa S, Jaiyen S, Khaithong W (2012) Effect of folic acid supplementation on plasma total homocysteine levels and glycemic control in patients with type 2 diabetes: a systematic review and meta-analysis. Diabetes Res Clin Pract 98: $151-158$

Weitgasser R, Galvan G, Malaimare L, Derflinger I, Hedegger M, Lang J, Iglseder B, Ladurner G, Paulweber B (2004) Cholesteryl ester transfer protein TaqIB polymorphism and its relation to parameters of the insulin resistance syndrome in an Austrian cohort. Biomed Pharmacother 58:619-627

WHO (2000) Obesity: preventing and managing the global epidemic. Report of a WHO Consultation, WHO Technical Report Series 894, WHO, Geneva; chapters 4-5

WHO (2003) Diet, nutrition and the prevention of chronic diseases. Report of a WHO Study Group. Technical Report Series 916, WHO, Geneva, chapter 5

WHO (2004) Vitamins and mineral requirements in human nutrition. WHO and FA, Rome

Yoo S, Nicklas T, Baranowski T, Zakeri IF, Yang SJ, Srinivasan SR et al (2004) Comparison of dietary intakes associated with metabolic syndrome risk factors in young adults: the Bogalusa Heart Study. Am J Clin Nutr 80:841-848

Zhan S, Ho SC (2005) Meta-analysis of the association of the Trp64Arg polymorphism in the beta3 adrenergic receptor with insulin resistance. Obes Res 13:1709-1719 